\title{
Productive response of hair ewes crossed with Damara and Dorper and growth of their lambs
}

[Resposta produtiva de ovelhas de cabelo cruzado com Damara e Dorper e crescimento de seus cordeiros]

T. Salinas-Rios ${ }^{1}$, J.A. Ramírez-Godínez ${ }^{2}$., F.A. Rodríguez-Almeida ${ }^{2}$, J. Hernández-Bautista ${ }^{1}$, N. Torres-Salado ${ }^{3 *}$, J. Herrera-Pérez ${ }^{4}$

\author{
${ }^{1}$ Universidad Autónoma Benito Juárez de Oaxaca - FMVZ - Oaxaca, México \\ ${ }^{2}$ Facultad de Zootecnia - Universidad Autónoma de Chihuahua - Chihuahua, México \\ ${ }^{3}$ Universidad Autónoma de Guerrero - Unidad Académica de Medicina Veterinaria y Zootecnia - Guerrero, México \\ ${ }^{4}$ Programa de Ganadería - Colegio de Postgraduados -Campus Montecillo - Montecillo, México
}

\begin{abstract}
Profitability of sheep production depends on the reproductive response of ewes and growth of their lambs, which can be improved through the ram genotype. The aim of this study was to evaluate the reproductive response of Blackbelly $(\mathrm{Bb})$, Pelibuey $(\mathrm{Pb})$, Katahdin (Kat) and Dorper (Dor) ewes crossed with Damara (Dam) and Dor rams and the growth of their offspring. To measure percentage of single and multiple lambings (MLP), $234 \mathrm{Bb}, \mathrm{Pb}$, Kat and Dor ewes were used. To measure lamb growth, the offspring of 86 $\mathrm{Bb} \times \mathrm{Pb}(\mathrm{BbPb})$ ewes and 73 Kat x Dor (KatDOR) ewes were used. Four Dor x BbPb, six Dam x BbPb and six Dam x KatDor lambs were slaughtered for carcass assessment. MLP was analyzed with the CATMOD procedure considering the factors age and breed. Lamb growth data were analyzed with the MIXED procedure, and those of carcass characteristics with the GLM procedure of SAS, using weight at slaughter as covariable. MLP was higher $(\mathrm{P}<0.05)$ in $\mathrm{Bb}$ than in Dor. The Dor $\mathrm{x} \mathrm{BbPb}$ lambs were heavier $(\mathrm{P}<0.05)$ at birth than $\mathrm{Dam} \times \mathrm{BbPb}$. Of the lambs from single and multiple births, the KatDor lambs were heavier $(\mathrm{P}<0.05)$ at birth than $\mathrm{BbPb}$ lambs. The female lambs of Dor rams had higher $(\mathrm{P}<0.05)$ weight gain after weaning than those of Dam rams. Carcass dressing, subcutaneous fat, and primal cut yield were not different $(\mathrm{P}>0.05)$ by effect of ram breed. It is concluded that $\mathrm{Bb}$ ewes are more prolific than Dor ewes; male lambs of Dam rams had post-weaning growth response and carcass yield similar to those of Dor rams, although the female lambs of Dor rams were heavier than those of Dam rams.
\end{abstract}

Keywords: Lambs, breeding, weaning, ewes, lambing

\section{RESUMO}

Rentabilidade da produção de ovinos depende da resposta reprodutiva de ovelhas e do crescimento de seus cordeiros, o que pode ser melhorado por meio do genótipo masculino. O objetivo deste estudo foi avaliar o desempenho reprodutivo de ovinos Blackbelly (Bb), Pelibuey (Pb), Katadin (Kat) e Dorper (Dor) e o crescimento de cordeiros com carneiros Damara (Dam) e Dor. Para medir a porcentagem de partos simples e múltiplas (MLP), foram utilizados 234 ovelhas Bb, PB, Kat e Dor. Para medir o crescimento dos cordeiros, foram utilizadas 86 ovelhas $\mathrm{Bb} \times \mathrm{Pb}(\mathrm{BbPb})$ e 73 Kat $\times$ Dor (KatDOR). Quatro cordeiros Dor x BbPb, seis Dam x BbPb e seis Dam x KatDor foram sacrificados para avaliação de carcaça. MLP foi analisada com o procedimento CATMOD, considerando-se fatores como idade e raça. Dados de crescimento do cordeiro foram analisados com o procedimento MIXED, e as de características de carcaça com o procedimento GLM do SAS, utilizando-se peso ao sacrifício como covariável. MLP foi maior $(P<0.05)$ em $B b$ do que em Dor. Os cordeiros Dor x BbPb foram mais pesados $(P<0.05)$ no nascimento do que Dam x BbPb. Em partos simples e múltiplos, os cordeiros de ovelhas KatDor foram mais pesados $(P<0.05)$ no momento do nascimento de cordeiros $B b P b$. As cordeiras de carneiros Dor apresentaram maior $(P<0.05)$ ganho de peso após o desmame do que as de

Recebido em 13 de abril de 2015

Aceito em 10 de maio de 2016

* Autor para correspondência (corresponding author)

E-mail: nivigas@yahoo.com.mx 
carneiros Dam. O rendimento de carcaça, a espessura da gordura subcutânea e o rendimento de corte primal não foram diferentes por efeito da raça de carneiro. Conclui-se que as ovelhas Bb são mais prolíficas do que as ovelhas Dor; cordeiros de carneiros Damara tiveram resposta de crescimento pósdesmame e rendimento de carcaça semelhantes aos dos carneiros Dor, embora Dorper cordeiras fossem mais pesadas do que as de Damara.

Palavras-chave: cordeiros, reprodução, desmame, ovelhas, parto

\section{INTRODUCTION}

Reproductive characteristics, body growth and meat yield determine rentability of a sheep production unit, for which the ram and ewe breed is determinant. Regarding the ewe, Blackbelly $(\mathrm{Bb})$ and Pelibuey $(\mathrm{Pb})$ are prolific breeds adapted to tropical conditions, but their growth rates are low (González et al., 2002; Macedo and Arredondo, 2008). Dorper ewes achieve daily weight gain of 240 to $280 \mathrm{~g}$ under different environmental conditions (Cloete et al., 2000), while Katahdin ewes are outstanding for their good productive response in terms of the number of live-born lambs and meat production. Crosses with Dorper (Dor) and Katahdin (Kat) breeds have been used to increase meat production. Regarding the ram breed, crossing hair sheep ewes with Dor rams results in offspring with better weight gain (Macías-Cruz et al., 2010), while crossing Damara (Dam) rams with Merino ewes increases weight gain of their lambs at five months of age, relative to those of pure Merino (Fleet et al., 2002). The Dam breed has been introduced in Mexico due to their rusticity, maternal skill and ability to cover long grazing distances, but there are no studies on the productive response of their offspring when they are crossed with hair sheep ewes. For this reason, the aim of this study was to assess the percentage of multiple births of Kat, Dor, $\mathrm{Pb}$, and $\mathrm{Bb}$ ewes and lamb growth and carcass characteristics of the offspring when they are bred with Dam and Dor rams.

\section{MATERIALS AND METHODS}

The study was conducted in a privately owned flock in Tlacolula, Oaxaca, located at $6^{\circ} 57^{\prime} \mathrm{N}$, $96^{\circ} 28^{\prime} \mathrm{W}$ and altitude of $1620 \mathrm{~m}$. The climate is dry steppe, with a mean annual temperature of $18^{\circ} \mathrm{C}$ (García, 1998).

The percentage of multiple lambings was calculated with 234 records of ewes of the breed groups $\mathrm{Bb}, \mathrm{Pb}$, Dor, and Kat, which were classified into groups of younger or older than 4 years of age. The ewes were confined during the night and grazed on Banderita (Bouteloua curtipendula) and Buffel (Cenchrus ciliaris) grass and Huizache (Acacia farnesiana) trees. During periods of scarce forage, they received $300 \mathrm{~g} \mathrm{~d}^{-1}$ growth concentrate (Tab. 1) and bean and maize harvest residues and alfalfa hay. The ewes mated in continuous breeding year round with Dam or Dor rams. Thirty days before lambing they were kept in confinement and received $400 \mathrm{~g} \mathrm{~d}^{-1}$ lactation concentrate (Tab. 2) and had free access to maize and bean harvest residues and alfalfa hay. Lambing occurred from January to July and was classified as single or multiple (two or more lambs born alive).

The effect of ram breed and ewe race group on birth weight, weaning weight and post-weaning weight gain of the lambs was determined with a second lot of ewes two to four years old, crosses of Pelibuey x Blackbelly ( $\mathrm{BbPb}, \mathrm{n}=86)$, and of Katahdin $x$ Dorper (KatDor, $n=73$ ) 20 days after weaning. The ewes received $10 \mathrm{mg}$ of ivermectin $50 \mathrm{~kg}^{-1}$ live weight and 3 days later they were synchronized with an intravaginal device $\left(\mathrm{CIDR}^{\circledR}\right)$ for $12 \mathrm{~d}$. When the device was removed they were administered 250IU intramuscular PMSG. Twenty-four $h$ after withdrawing the CIDR, estrus was detected with rams covered with an apron. The ewes were mated in the same proportion with purebred Dor $(n=4)$ and Dam $(n=4)$ rams. Four types of crosses resulted: Dam x BbPb, Dam x KatDor, Dor x BbPb, and Dor x KatDor. During synchronization $0.5 \mathrm{~kg} \mathrm{~d}^{-1}$ concentrate was offered to each ewe; the concentrate contained $13.42 \% \mathrm{CP}$ and $2.76 \mathrm{Mcal}$ $\mathrm{kg}^{-1}$ EM. The ewes were housed in corrals where they were given free access to water, maize and bean harvest residues and alfalfa hay. Two weeks before parturition and until weaning, the ewes were housed in corrals where they were given $300 \mathrm{~g} \mathrm{~d}^{-1}$ lactation feed, forage (maize and bean harvest residues and alfalfa hay) and free access to water (Tab. 1). The corrals have trap pens which only lambs can access, and as of $15 \mathrm{~d}$ of 
age the lambs were given feed (Tab. 1). Weaning was done at $65 \mathrm{~d}$ of age, and for $15 \mathrm{~d}$ the lambs had free access to forage (maize and bean harvest residues and alfalfa hay) and weaning concentrate. After this period, males were given free access to fattening concentrate and females to growing concentrate for $54 \mathrm{~d}$ (Tab. 1). The diets were adjusted according to the requirements of Nutrient... (1985).

Table 1. Nutrients for sheep diets at five physiological stages

\begin{tabular}{lccccc}
\hline Nutrient & Lactation & Pre-weaning & Weaning & Growth & Fattening \\
\hline Dry matter (\%) & 86.7 & 87.7 & 87.7 & 87.8 & 87.2 \\
Crude protein (\%) & 21.42 & 17.9 & 16.9 & 15.1 & 14.5 \\
EM (Mcal kg ${ }^{-1}$ ) & 2.9 & 2.8 & 2.8 & 2.7 & 2.7 \\
Calcium (\%) & 0.82 & 0.54 & 0.54 & 0.51 & 0.55 \\
Phosphorus (\%) & 0.38 & 0.24 & 0.24 & 0.24 & 0.28 \\
\hline
\end{tabular}

NRC (1985).

To evaluate the effect of ram breed and the cross of Dam with Dor ewes on carcass characteristics, at the end of fattening, three treatments were formed consisting of the following crosses: T1, Dam x KatDor $(n=6)$; T2, Dam x BbPb $(n=6)$, and $\mathrm{T} 3$, Dor $\mathrm{x} \mathrm{BbPb}(\mathrm{n}=4)$. Average weight was $33.6 \mathrm{~kg}$. The lambs were sacrificed and the hot carcass was weighed and refrigerated at $4^{\circ} \mathrm{C}$ for 18h. After this period, the cold carcass was weighed, the Longisimuss dorsi area between the $12^{\text {th }}$ and $13^{\text {th }}$ rib was calculated, and dorsal fat thickness was measured on the $12^{\text {th }} \mathrm{rib}$, on the rump and at the base of the tail with a Vernier. Primal cut yield of the carcass (tail, leg, neck, loin, rib, foreshank, flank, hindshank, and skirt) and surplus fat.

The percentage of single and multiple births was analyzed with the CATMOD procedure considering the principal effects breed, age, and their interaction. Weight at birth of the lambs was analyzed with the MIXED procedure, which included the fixed effects of the ram breed, ewe race group, type of lambing, sex and their possible interactions, as well as the random effects of the sire within the sire breed and the dam within the dam breed. The statistical procedure for weaning weight was similar to that used in the analysis of weight at birth, but the fixed effect type of lambing was changed for type of weaning. Due to the differences in postweaning feeding, the analysis of post-weaning weight was done in male and female lambs separately. The model included the ram race, the mother's race group, type of weaning and their possible interactions, as well as the random effects of the sire within the sire breed and the dam within the dam breed as fixed effects. Carcass assessment was done with the GLM procedure, considering the cross as fixed effect and weight at sacrifice as co-variable (SAS, 2002).

\section{RESULTS AND DISCUSSION}

For groups $\mathrm{Bb}$, Dor, Kat, and $\mathrm{Pb}$, lambs born alive per ewe were $1.77,1.27,1.39$ and 1.42 , respectively. In Figure 1, it is observed that $\mathrm{Bb}$ has a larger percentage of multiple births than Dor $(\mathrm{P}<0.05)$. The average (1.55) number of live-born lambs in $\mathrm{Pb}$ in this study is similar to that reported by Macedo and Alvarado (2005), although it contrasts with 2.24 lambs born alive per ewe, with intensive feeding evaluated by these authors. Hinojosa et al. (2005) analyzed the records of grazing ewes in the humid tropics and found that $\mathrm{Bb}$ is more prolific than $\mathrm{Pb}$ or crosses with Dor and Kat in different years. In this study $\mathrm{Bb}$ had a higher percentage of multiple births, coinciding with findings of López-Carlos et al. (2010), who report that $\mathrm{Bb}$ is more prolific than Dor, Kat, or $\mathrm{Pb}$. But in our study there were 1.27 lambs born alive per Dor ewe, higher than the 1.16 lambs per parturition of ewes synchronized with medroxyprogesterone acetate or flurogestone actetate sponges reported by Zeleke et al. (2005). These authors increased the number of lambs born to 1.26 and 1.47 by applying 300IU PMSG $24 \mathrm{~h}$ before withdrawing the sponge. These values are similar to those of Dor ewes in our study, although the ewes were not synchronized with hormone treatments that might have changed their reproductive response. 


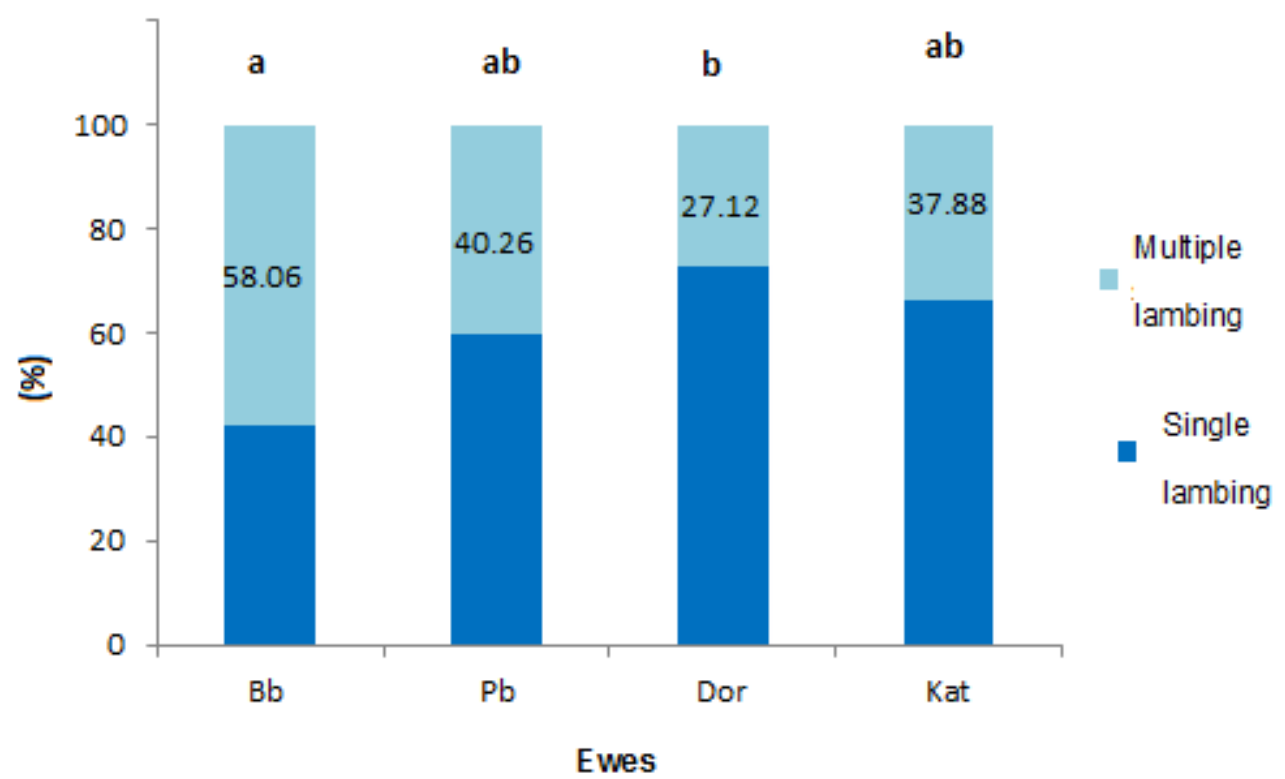

Figure 1. Percentage of single and multiple lambings of $\mathrm{Bb}, \mathrm{Pb}$, Dor, and Kat ewes.

${ }^{\mathrm{a}, \mathrm{b}}$ Different letters indicate significant statistical differences $(\mathrm{P}<0.05)$ among groups. $\mathrm{Bb}=$ Blackbelly, $\mathrm{Pb}=$ Pelibuey, Dor=Dorper, Kat=Katahdin.

Ewes that were younger than four years old had 1.26 lambs born alive, while ewes four years or older had 1.55 lambs; that is, the percentage of multiple lambings was higher $(\mathrm{P}<0.05)$ for the older ewes (Fig. 2). A lower number of lambs per parturition has also been observed in Suffolk and Targhee ewes less than two years old (Bunge et al., 1993). Moreover, Burke (2005) reported that lamb litter weight increases with age of Kat, Dor and St. Croix ewes; this may be due to the larger number of multiple lambings of ewes older than 1 year, relative to younger ewes.

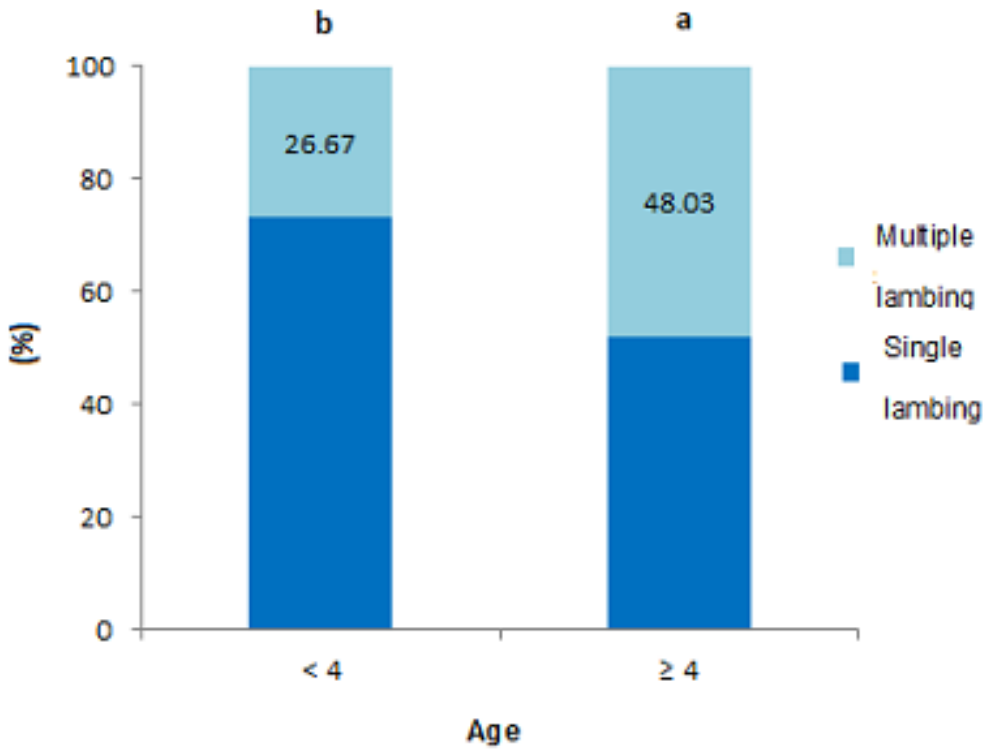

Figure 2. Percentage of single and multiple lambings of ewes less than four years old and ewes older than four years old.

${ }^{\mathrm{a}, \mathrm{b}}$ Different letters indicate significant difference between age groups $(\mathrm{P}<0.05)$. 
Among the female lambs there was no difference due to ram breed or racial group of the mother (Fig. 3). Among the single male lambs born to $\mathrm{BbPb}$ mothers, it was found that the offspring of Dor rams $(3.88 \mathrm{~kg})$ were heavier $(\mathrm{P}<0.05)$ at birth than those of Dam rams $(2.87 \mathrm{~kg})$; this is because Dor rams are heavier than Dam rams. Single birth $\mathrm{BbPb}$ male lambs were $383 \mathrm{~g}$ lighter $(\mathrm{P}<0.04)$ than KatDor male lambs, while twin lambs were $660 \mathrm{~g}$ lighter. This may have been due to the heavier weight of the KatDor ewes since $\mathrm{Bb}$ and $\mathrm{Pb}$ are smaller breeds (ArredondoRuiz et al., 2013). López-Carlos et al. (2010) report that pure bred Dor and Kat ewes have heavier lambs than $\mathrm{Bb}$ and $\mathrm{Pb}$. Hinojosa et al. (2005) report birth weights of $2.93 \mathrm{~kg}$ for Dor $\mathrm{x}$ $\mathrm{Pb}$, similar to female and male Dor $\mathrm{x} \mathrm{BbPb}$ offspring from multiple lambings, but lower than lambs from single births. All of the birth weights of Dor ram offspring are lower than the weights reported by Snowder and Duckett (2003) for offspring of Dor rams crossed with Columbia ewes. This may be due to the larger size of Columbia ewes. For pure Dor, birth weights of $3.1 \mathrm{~kg}$ have been reported (Burke and Apple, 2007). Birth weights of pure Katahdin are reported at $3.6 \mathrm{~kg}$ (Burke et al., 2003) and $3.4 \mathrm{~kg}$ (Burke and Apple, 2007).

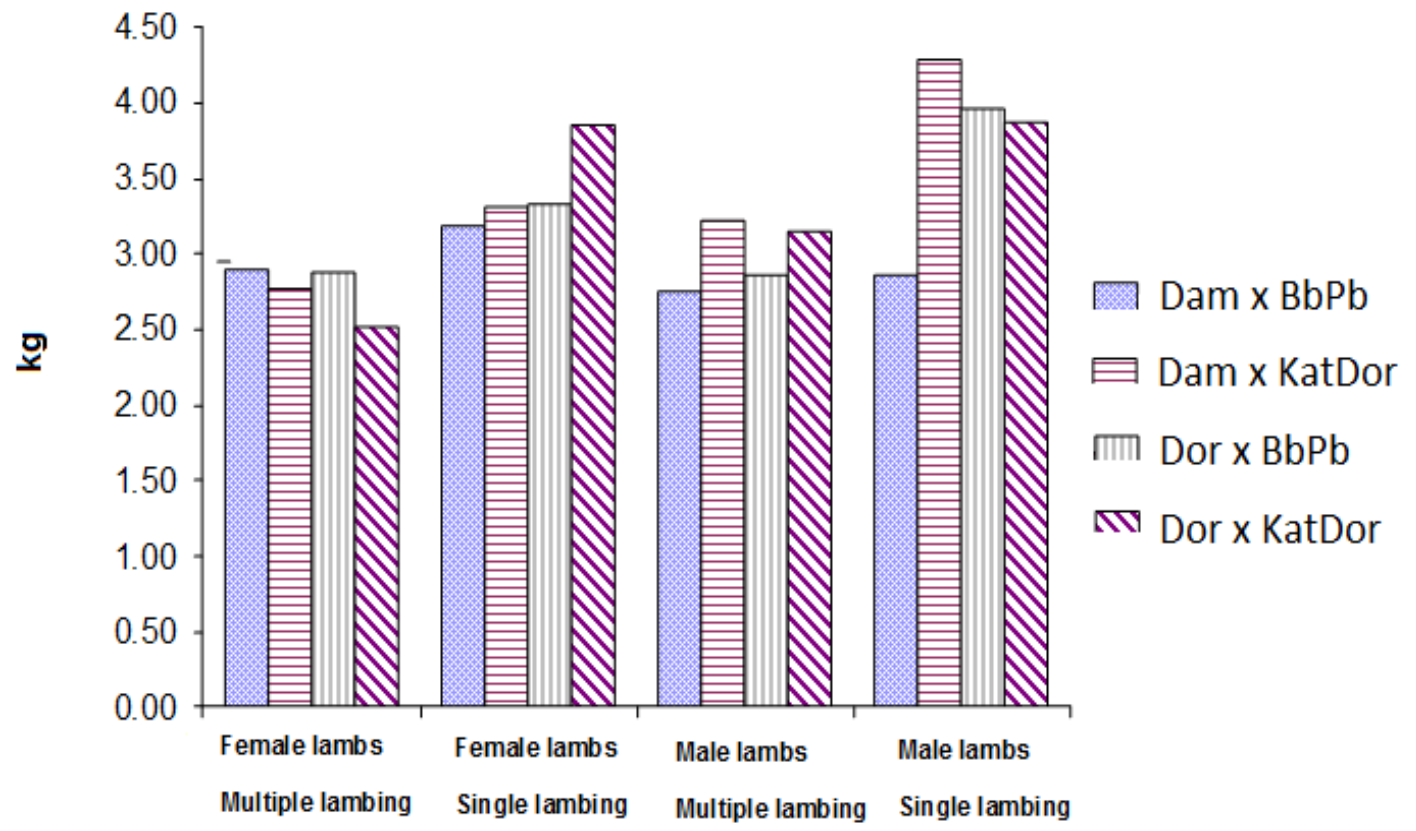

Figure 3. Birth weights of offspring of Dor and Dam mated with BbPb or KatDor ewes.

Dam: Damara, Dor: Dorper, KatDor: Katahdin-Dorper and BbPb: Blackbelly-Pelibuey.

Weaning weight of female lambs from KatDor ewes crossed with Dor rams $(21.18 \mathrm{~kg})$ was higher $(\mathrm{P}<0.01)$ than those from KatDor ewes mated with Dam rams $(15.6 \mathrm{~kg})$. There were no differences $(\mathrm{P}>0.05)$ in weaning weight of male lambs by effect of ram or ewe breed. Hinojosa et al. (2005) registered an average weaning weight ( $83 \mathrm{~d}$ old) of $12.44 \mathrm{~kg}$ for female and male Dor $\mathrm{x}$ $\mathrm{Pb}$ lambs raised in tropical conditions. This weight is lower than that of Dor ram offspring weaned at $65 \mathrm{~d}$ reported in our study. The better productive response of the lambs of this research may have been due to the balanced diet that covered their nutritional requirements.

Lambs from South Africa $(21.7 \mathrm{~kg}$ ) have better weaning weights than those raised in the US (19.4kg) (Notter et al., 2004); these averages are higher than the live weight of Dor ram offspring when they are from multiple weaning but are similar to the average of single weaning offspring of our study. Weaning weights at 58-66 $\mathrm{d}$ of $19.2 \mathrm{~kg}$ have been reported for purebred Katahdin lambs (Burke et al., 2003). 


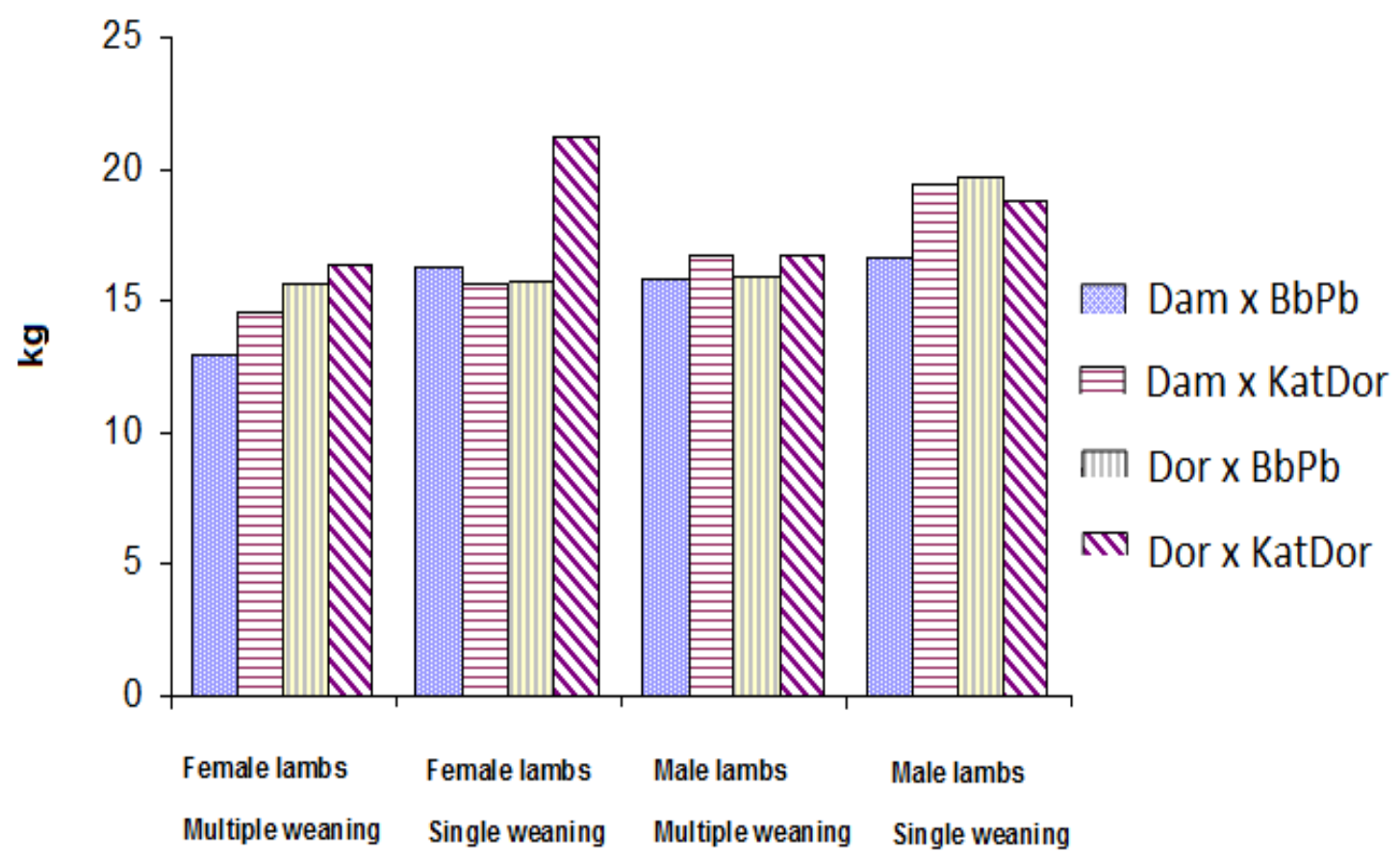

Figure 4. Weaning weight of offspring of Dor and Dam rams crossed with BBPB or KATDOR group ewes.

Dam: Damara, Dor: Dorper, KATDOR: Katahdin-Dorper and BBPB: Blackbelly-Pelibuey.

Post-weaning daily weight gain of male lambs was not affected $(\mathrm{P}<0.05)$ by ram breed, group of the mother, or weaning type (Tab. 3). Female lambs of Dor rams had a post-weaning daily weight gain $16.6 \%$ higher $(\mathrm{P}<0.05)$ than female lambs of Dam Rams (Tab. 2). These postweaning gains are similar to those reported for the offspring of Dor (239g), Columbia (239g), and Suffolk $(259 \mathrm{~g})$ ram mated with Columbia ewes (Snowder and Duckett, 2003). However, the post-weaning gain obtained in our study for females and males is higher than that reported by Wildeus et al. (2005), who achieved daily weight gains of $73 \mathrm{~g}$ for female and $109 \mathrm{~g}$ for male $\mathrm{Bb}$ and Kat fed forage and concentrate with $15.7 \%$ $\mathrm{CP}$ administered at $1.5 \%$ live weight. The higher post-weaning weight gain of Dor ram offspring, compared with Dam offspring, is possibly because Dor ewe is a meat breed that can reach a weight of $70.2 \mathrm{~kg}$ or more depending on feed management (Burke, 2005).

Table 2. Post-weaning daily weight gain $\left(\mathrm{g} \mathrm{d}^{-1}\right)$ for male and female lambs by ram breed, ewe race group and weaning type at $69 \mathrm{~d}$ post-weaning

\begin{tabular}{lcc}
\hline & Female lambs & Male lambs \\
\hline Ram breed & & \\
DAM & $198.87 \pm 10.45 \mathrm{~b}$ & $263.00 \pm 7.76$ \\
DOR & $238.36 \pm 12.66 \mathrm{a}$ & $249.51 \pm 11.08$ \\
Ewe race group & & \\
BbPb & $210.04 \pm 9.47$ & $252.63 \pm 8.84$ \\
KatDor & $227.19 \pm 11.99$ & $259.88 \pm 9.7$ \\
Weaning type & & \\
Multiple & $212.57 \pm 11.28$ & $257.99 \pm 9.34$ \\
Single & $224.66 \pm 10.49$ & $254.52 \pm 9.13$ \\
\hline
\end{tabular}

Different letters indicate significant differences between rows $(\mathrm{P}<0.05)$. 
Commercial and real carcass dressing were not modified $(\mathrm{P}>0.05)$ by crosses of Dam and Dor rams with $\mathrm{BbPb}$ ewes or with Dam $\mathrm{x}$ KatDor (Tab. 3). This contrasts with Tshabalala et al. (2003), who found that carcass dressing of the Dam breed is lower than that of the Dor breed because of the heavier tail and skin of Dam. Although in our study the percentage of tail (0.97 $\%$ ) increased when Dam was crossed with $\mathrm{BbPb}$ ewes, relative to the Dor $\mathrm{x} \mathrm{BbPb}$ cross $(0.65 \%)$, there was no effect on carcass dressing. Commercial carcass dressing found for three crosses are similar to the carcass dressing of $52 \%$ found for 3/8 Dor (Daniel and Held, 2005) and for pure Katahdin (53.7\%) (Burke et al., 2003). The percentage of kidney fat was higher $(\mathrm{P}<0.05)$ for the offspring of the Dam $\mathrm{x}$ KatDor cross than for those of Dam $\mathrm{x} \mathrm{BbPb}$ or Dor $\mathrm{x}$ $\mathrm{BbPb}$. Because the Dam breed has been characterized for the large quantity of subcutaneous fat deposited in the rump area and tail (Tshabalala et al., 2003), fat thickness was measured at three points of the carcass. It was found that in the evaluated crosses there was no modification in dorsal or rump fat, nor in the fat at the base of the tail. In this regard, Kremer et al. (2004) proved that in the measure that weight at sacrifice increases, so does the proportion of fat in the carcass since in early growth phases, subcutaneous fat deposits are scarce. The proportion of primal cuts, such as leg, loin and flank, was not modified, although the percentage of neck was lower $(\mathrm{P}<0.05)$ in the Dor $\mathrm{x} \mathrm{BbPb}$ cross (Tab. 3). Almeida et al. (2013) reported that Dam sheep have a larger proportion of neck than Dor, but there are no differences in leg and loin.

Table 3. Carcass assessment of Dorper and Damara crosses with hair sheep ewes

\begin{tabular}{lccc}
\hline Characteristic, $\%$ & Dam $\times$ KatDor & Dam $\times \mathrm{BbPb}$ & Dor x BbPb \\
\hline Commercial carcass dressing & $52.66 \pm 0.73$ & $54.52 \pm 0.73$ & $54.23 \pm 0.89$ \\
Real carcass dressing & $57.91 \pm 1.61$ & $58.95 \pm 1.26$ & $59.04 \pm 1.89$ \\
Kidney fat & $1.26 \pm 0.10 \mathrm{a}$ & $0.83 \pm 0.10 \mathrm{~b}$ & $0.69 \pm 0.12 \mathrm{~b}$ \\
Rumen fat & $2.89 \pm 0.21$ & $2.28 \pm 0.21$ & $2.27 \pm 0.25$ \\
Area of Longisimuss dorsi muscle & $6.24 \pm 0.03$ & $6.13 \pm 0.3$ & $6.45 \pm 0.4$ \\
Dorsal fat & $3.58 \pm 0.4$ & $3.08 \pm 0.4$ & $3.0 \pm 0.49$ \\
Rump fat & $11.17 \pm 1.9$ & $15.0 \pm 1.9$ & $12.0 \pm 2.3$ \\
Fat at tail base & $9.0 \pm 2.3$ & $11 \pm 2.3$ & $7.75 \pm 2.8$ \\
Tail & $0.87 \pm 0.15 \mathrm{a}$ & $0.97 \pm 0.15 \mathrm{a}$ & $0.65 \pm 0.18 \mathrm{~b}$ \\
Leg & $30.32 \pm 0.58$ & $29.56 \pm 0.58$ & $29.72 \pm 0.71$ \\
Neck & $10.03 \pm 0.34 \mathrm{a}$ & $9.9 \pm 0.34 \mathrm{a}$ & $8.47 \pm 0.42 \mathrm{~b}$ \\
Loin & $23.25 \pm 0.64$ & $23.72 \pm 0.64$ & $24.01 \pm 0.79$ \\
Rib & $8.98 \pm 0.37$ & $9.46 \pm 0.37$ & $8.83 \pm 0.45$ \\
Foreshank & $15.75 \pm 0.83$ & $15.69 \pm 0.83$ & $17.21 \pm 1.01$ \\
Skirt & $2.03 \pm 0.22$ & $2.07 \pm 0.22$ & $1.94 \pm 0.27$ \\
Hind shank & $2.44 \pm 0.12$ & $2.49 \pm 0.12$ & $2.67 \pm 0.15$ \\
Flank & $5.30 \pm 0.23$ & $4.88 \pm 0.23$ & $4.93 \pm 0.28$ \\
Surplus fat & $1.13 \pm 0.19$ & $1.17 \pm 0.19$ & $1.38 \pm 0.24$ \\
\hline
\end{tabular}

Different letters indicate significant differences between columns $(\mathrm{P}<0.05)$.

DAM: Damara, DOR: Dorper, KatDor: Katahdin-Dorper and BbPb: Blackbelly-Pelibuey

\section{CONCLUSION}

Blackbelly ewes are more prolific than Dorper ewes. Katahdin-Dorper ewes gave birth to heavier male lambs than Blackbelly-Pelibuey ewes. At weaning, female lambs from KatahdinDorper ewes crossed with Dorper rams were heavier than lambs from ewes of the same group crossed with Damara rams. In fattening of the male lambs, no effect of the ram or ewe breed on daily weight gain was found, although in the case of the females, Dor ram offspring achieved higher weight gain. In terms of carcass dressing, subcutaneous fat and important primal cuts characteristics, there was no effect of crossing Damara and Dorper rams with BlackbellyPelibuey ewes or of the Damara $x$ Dorper cross. 


\section{REFERENCES}

ALMEIDA, A.M.; KILMINSTER, T.; SCANLON T. et al. Assessing carcass and meat characteristics of Damara, Dorper and Australian Merino lambs under restricted feeding. Trop. Anim. Health Prod., v.45, p.1305-1311, 2013.

ARREDONDO-RUIZ, V.; MACEDO-BARRAGÁN, R.; MOLINA-CARDENAS, J. et al. Morphological characterization of pelibuey sheep in Colima, México. Trop. Anim. Health Prod., v.45, p.895-900, 2013.

BUNGE, B.; THOMAS, D.L.; NASH, T.G.; FERNANDO, R.L. Performance of hair and prolific wool breeds of sheep in southern Illinois: effect of breed of service sire on lamb production of suffolk and targhee ewes. J. Anim. Sci., v.71, p.321-325, 1993.

BURKE, J.M. Lamb production of Dorper, Katahdin, and St. Croix bred in summer, winter, or spring in the southeastern United States. Sheep Goat Res. J., v.20, p.51-59, 2005.

BURKE, J.M.; APPLE, J.K. Growth performance and carcass trait of forage-fed hair sheep wethers. Small Ruminant Res., v.67, p.264-270, 2007.

BURKE, J.M.; APPLE, J.K.; ROBERTS, W.J. et al. Effect of breed-type on performance and carcass traits of intensively managed hair sheep. Meat Sci., v.63, p.309-315, 2003.

CLOETE, S.W.P.; SNYMAN, M.A.; HERSELMAN, M.J. Productive performance of dorper sheep. Small Ruminant Res., v.36, p.119-135, 2000.

DANIEL J.A.; HELD J. Carcass and growth characteristics of wheters sired by percentage white Dorper or Hampshire. Sheep Goat Res. J., v.20, p.4750,2005

FLEET, M.R.; BENNIE, M.J.; DUNSFORD, G.N. et al. Lamb production from Merino ewes to Merino or Damara rams. Aust. J. Exp. Agric., v.42, p.1027-1032, 2002.

GARCÍA., E. Modificaciones al sistema de clasificación climática de Köppen. 4.ed. México: UNAM, 1998. 220p.

GONZÁLEZ, G.R.; TORRES, H.G.; CASTILLO, A.M. Crecimiento de corderos blackbelly entre el nacimiento y el peso final en el trópico húmedo. Vet. Méx., v.33, p.443-453, 2002.

HINOJOSA, C.J.A.; GARCÍA, M.; OLIVA, H.J. Comportamiento reproductivo de ovejas blackbelly y sus cruzas con pelibuey, dorper y katahdin en Centla, Tabasco, México. In: MEMORIAS DEL SEMINARIO DE PRODUCCIÓN DE OVINOS EN EL TRÓPICO, 4., 2005, Villahermosa. Anales...
Villahermosa: [Universidad Juárez Autónoma de Tabasco], 2005. p.56-62.

LÓPEZ-CARLOS, M.A.; RAMÍREZ, R.G.; AGUILERA-SOTO, J.I. Size and shape analyses in hair sheep ram lambs and its relationships with growth performance. Livest. Sci., v.131, p.203-2011, 2010.

MACEDO, R.; ALVARADO, Y.A. Efecto de la época de monta sobre la productividad de ovejas pelibuey bajo dos sistemas de alimentación en Colima, México. Arch. Zootec., v.54, p.51-62, 2005.

MACEDO, R.; ARREDONDO, Y.V. Efecto del sexo, tipo de nacimiento y lactancia sobre el crecimiento de ovinos pelibuey en manejo intensivo. Arch. Zootec., v.218, p.219-228, 2008.

MACÍAS-CRUZ, U.; ALVAREZ-VALENZUELA, F.D.; RODRÍGUEZ-GARCÍA， J. Crecimiento y características de canal en corderos Pelibuey puros y cruzados F1 con razas Dorper y Katahdin en confinamiento. Arch. Med. Vet., v.42, p.147-154, 2010.

NOTTER, D.R.; GREINER, S.P; WAHLBERG, M.L. Growth carcass characteristics of lambs sired by Dorper and Dorset rams. J. Anim. Sci., v.82, p.13231328,2004

NUTRIENT requirements of sheep. 6.ed. Washington: National Academy Press, 1985. p.109.

SAS user's guide: procedure statistics, version 9 Cary: SAS, 2002.

SNOWDER, G.D.; DUCKETT, S.K. Evaluation of the south African dorper as a terminal sire breed for growth, carcass, and palatability characteristics. J. Anim. Sci., v.81, p.368-375, 2003.

TSHABALALA, P.A.; STRYDOM, P.E.; WEBB, E.C.; KOCK, H.L. Meat quality of designated south African indigenous goat and sheep breeds. Meat Sci., v.65, p.563-570, 2003.

WILDEUS, S.; TURNER, K.E.; COLLINS, J.R. Growth performance of Barbados blackbelly, Katahdin and St. Croix hair sheep lambs fed pasture or hay-based diets. Sheep Goat Res. J., v.20, p.37-41, 2005.

ZELEKE, M.; GREYLING, J.P.; SCHWALBACH, L.M. et al. Effect of progestagen and PMSG on oestrous synchronization and fertility in Dorper ewes during the transition period. Small Ruminant Res., v.56, p.47-53, 2005. 